ФОРМУВАННЯ ФАХОВИХ КОМПЕТЕНТНОСТЕЙ ПЕДАГОГІВ ПРОФЕСІЙНОГО НАВЧАННЯ І ФАХІВЦІВ СФЕРИ ОБСЛУГОВУВАННЯ

ПІД ЧАС ВИВЧЕННЯ ОСВІТНЬОГО КОМПОНЕНТА «ОСНОВИ ПРОЄКТУВАННЯ ТА МОДЕЛЮВАННЯ» 3 УРАХУВАННЯМ ВИМОГ СУЧАСНОГО СУСПІЛЬСТВА

\title{
FORMATION OF PROFESSIONAL COMPETENCES PROFESSIONAL TRAINING TEACHERS AND SERVICE SPECIALISTS IN THE STUDY OF THE EDUCATIONAL COMPONENT "FOUNDATIONS DESIGNING AND MODELING" CONSIDERING REQUIREMENTS OF MODERN SOCIETY
}

\begin{abstract}
У статті проаналізовано сучасний стан формування фрахових компетентностей майбутніх педагогів професійного навчання і фрахівців сорери обслуговування під час вивчення освітнього компонента «Основи проєктування та моделювання», адже в епоху інсрормаційно-високотехнологічного суспільства на першому місці має бути людина освічена і культурна, творча та ініціативна, з високим рівнем професіоналізму і мобільності, а головне, із прагненням навчатися протягом усього життя $і$ перекваліфріковуватись у нових умовах виробничтва та освітнього прочесу. Встановлено, що вивчення основ проєктування і моделювання дозволяє зорієнтувати здобувачів освіти не лише на пізнання і перетворення світу, на взаємодію із навколишнім середовищем, але і на проєктування нової реальності на основі сучасних концепцій, понять, методів $i$ технологій художнього конструювання та моделювання, на фрормування свідомого педагога $i$ фрахівця із достатнім освітньо-культурним, творчим, комунікабельним, фраховим рівнем, який відповідав би вимогам національної освітньої системи і міжнародних стандартів та був конкурентоспроможним на ринку праці. Проведене дослідження дозволило сорормувати основні фрахові компетентності, принципи організації та науково-обгрунтовані підходи під час навчання, ознаки інноваційного художньо-педагогічного освітнього середовища, мету і завдання дисципліни, особливості їі викладання, які у поєднанні із застосуванням сучасних технологій навчання (інформаційно-комунікаційних, інтерактивних, проєктних тощо), дозволять досягти ефективних результатів у формуванні професійної компетентності майбутніх педагогів профессійного навчання і фрахівців сорери обслуговування, а також сприятимуть всебічному розвитку здобувачів освіти, їхньому самоствердженню і самореалізації у майбутній професійній діяльності.
\end{abstract}

докт. фрілос. наук,

доцент кафедри професійної освіти трудового навчання та технологій Рівненського державного гуманітарного університету

DOI https://doi.org/10.32843/26636085/2021/41/2.15
Ключові слова: фахові компетентності, освітній компонент, педагог профресійного навчання, фрахівець сфрери обслуговування, проєктування, моделювання.

The article analyzes the current state of formation of professional competencies of future teachers of vocational training and service professionals in the study of the educational component "Fundamentals of design and modeling", after all, in the era of information and high-tech society in the first place should be educated and cultured, creative and enterprising, with a high level of professionalism and mobility, and most importantly, with the desire to learn throughout life and retrain in new conditions of production and educational process. It is established that the study of the basics of design and modeling allows students to focus not only on knowledge and transformation of the world, on interaction with the environment, but also to design a new reality based on modern concepts, concepts, methods and technologies of artistic design and modeling, to form a conscious teacher and specialist with a sufficient educational, cultural, creative, communicative, professional level, which would meet the requirements of the national educational system and international standards and be competitive in the labor market. The study allowed to form the main professional competencies, principles of organization and scientifically based approaches in the learning process, signs of innovative artistic and pedagogical educational environment, the purpose and objectives of the discipline, the peculiarities of its teaching, which in combination with the use of modern learning technologies (information and communication, interactive, project, etc.), will achieve effective results in the formation of professional competence of future teachers of vocational training and service specialists, and will promote the comprehensive development of students, their self-affirmation and self-realization in future professional activities.

Key words: professional competences, educational component, teacher of professional training, specialist in the field of service, design, modeling.
Постановка проблеми у загальному вигляді та її зв'язок із важливими науковими чи практичними завданнями. У XXI столітті зі всіма його глобальними соціальними, політичними, технічними, інформаційно-високотехнологічними і науковими змінами потрібні кардинальні зміни і в освіті відповідно до тенденцій розвитку та запитів суспільства. Проте модернізація в освітній системі наштовхується на труднощі і часто не встигає за змінами в економіці, науці, техніці, технології, культурі, у соціальних відносинах і суспільній свідомості. Тому вдосконалення профресійнопедагогічної освіти має стати джерелом інновацій і кардинальних змін у розбудові нашої держави та українського суспільства. Адже у Законі про освіту чітко прописано: «Метою освіти є всебічний 
розвиток людини як особистості та найвищої цінності суспільства, її талантів, інтелектуальних, творчих і фрізичних здібностей; фрормування цінностей і необхідних для успішної самореалізації компетентностей; виховання відповідальних громадян, які здатні до свідомого суспільного вибору та спрямування своєї діяльності на користь іншим людям і суспільству, збагачення на цій основі інтелектуального, економічного, творчого, культурного потенціалу українського народу; підвищення освітнього рівня громадян задля забезпечення сталого розвитку України та її європейського вибору» [1]. Тому в епоху інфрормаційно-високотехнологічного суспільства на першому місці має бути людина і не просто людина, а людина освічена і культурна, творча та ініціативна, з високим рівнем професіоналізму і мобільності, а головне, із прагненням навчатися протягом усього життя і перекваліфіковуватись у нових умовах виробництва та освітнього процесу.

За переконаннями М.В. Ганжи [2, с. 174], сучасне суспільство має розробляти такі освітні та культурні стратегії і політику, які би сприяли передачі і збереженню культурних та естетичних цінностей і самобутніх рис, що розвивають і зміцнюють культурне розмаїття світу. Проблема відтворення інтелектуального і національного потенціалу суспільства, яка зумовлює зміни у його змісті і призводить до пошуку інноваційних підходів до підготовки майбутніх фрахівців, визначає особливі вимоги до системи професійної підготовки студентів, до розвитку їхньої проєктної культури і фрормування художнього досвіду, тривалий час розглядалась у контексті розвитку освіти і культури [3, с. 5]

У сучасних умовах розвитку суспільства інтеграція освітнього процесу і майбутньої профресійної діяльності вимагає цілеспрямовано задавати систему переходів від навчальної до професійної діяльності [4], тому саме компетентнісний підхід $€$ тим пріоритетним напрямом, який орієнтує на навчання, самовизначення, самоактуалізацію, соціалізацію і розвиток індивідуальності [5]. Через це постає проблема формування професійної компетентності майбутніх педагогів професійного навчання і фрахівців сфери обслуговування під час фрахової підготовки та створення педагогічних умов їхньої реалізації в умовах неперервної освіти, оскільки вона має відбуватись упродовж усього навчально-виховного процесу у закладах вищої освіти з урахуванням наукових підходів (компетентнісного, системного, індивідуального, особистісно орієнтованого) в умовах змішаної форми навчання (очної і дистанційної) та із застосуванням сучасних технологій навчання (інфрормаційно-комунікаційних, інтерактивних, проєктних тощо).

Аналіз останніх досліджень і публікацій. Сутність, структура, значення компетентнісного підходу у системі сучасної освіти висвітлені у працях багатьох науковців, таких як Н.М. Бібік, І.І. Драч, О.А. Дубасенюк, С.С. Вітвицька, І.О. Зимня, І.А. Зязюн, Г.А. Ларіонова, О.В. Овчарук, О.І. Пометун, В.Д. Шадрикова, А.В. Хуторський, В.В. Ягупов, І.С. Якиманська та інші. Фундаментальні положення і практичні рекомендації із питань профресійної освіти розкриті у працях В. Андріяшина, А. Вихруща, В. Гусєва, М. Деліка, А. Дьоміна, В. Качнева, М. Корця, Г. Левченка, Д. Лазаренка, В. Мадзігона, В. Сидоренка, А. Стахурського, В. Стешенка, Г. Терещука, Д. Тхоржевського, В. Харламенка, М. Ховрича та інших [5]. Питання професійної підготовки майбутніх кваліфрікованих робітників професійно-технічних навчальних закладів освіти досліджували Р. Гуревич, Й. Гушулей, Д. Закатнов, М. Кадемія, А. Литвин, В. Лозовецька, Л. Лук'янова, Г. Ничкало та інші; особливості фрормування професійних здібностей робітників сфери обслуговування - І. Жорова; фрормування художньо-творчих вмінь - Н. Котляревська, О. Отич; розвиток особистісно профресійних якостей - Н. Вінник та інші [6].

Виділення невирішених раніше частин загальної проблеми. Проблема фрормування фахових компетентностей майбутніх педагогів професійного навчання і фрахівців сфери обслуговування під час вивчення освітнього компонента «Основи проєктування та моделювання» має потребу у постійному розгляді та вивченні, адже змінюються вимоги сучасного суспільства до освітніх траєкторій, а стрімкий науково-технічний прогрес вносить значні корективи у швидкість та якість оброблення інфрормації. Тому вивчення основ проєктування та моделювання дозволяє зорієнтувати здобувачів освіти не тільки на пізнання і перетворення світу, на взаємодію із навколишнім середовищем, але і на проєктування нової реальності на основі сучасних концепцій, понять, методів і технологій художнього конструювання та моделювання, на фрормування свідомого педагога і фрахівця із достатнім освітньо-культурним, творчим, комунікабельним, фаховим рівнем, який відповідає вимогам національної освітньої системи і міжнародних стандартів, який має бути конкурентоспроможним на ринку праці. Таким чином, розбудова сучасної системи освіти (професійної, професійно-технічної, фрахової (передвищої), позашкільної освіти) потребує створення інноваційного художньопедагогічного освітнього середовища на основі використання як інорормаційно-комунікаційних технологій і конструкторсько-технологічної діяльності, так і на основі компетентнісного підходу під час фрахової підготовки педагогів професійного навчання і фрахівців сорери послуг, що, у свою чергу, сприятиме фрормуванню духовної культури, всебічному розвитку здобувачів освіти, 
самоствердженню та самореалізації у майбутній професійній діяльності.

Мета роботи - розкриття особливостей фрормування фрахових компетентностей майбутніх педагогів профресійного навчання і фрахівців сфери обслуговування під час вивчення основ проєктування та моделювання з урахуванням сучасних освітніх вимог.

Виклад основного матеріалу дослідження. У «Національному освітньому глосарії вищої освіти» фахова компетентність визначається як динамічна комбінація знань, умінь і практичних навичок, способів мислення, професійних, світоглядних і громадянських якостей, моральноетичних цінностей, яка визначає здатність особи успішно здійснювати професійну і подальшу навчальну діяльність, є результатом навчання на певному рівні вищої освіти [7, с. 25]. У дослідженнях Т. Сороки та В. Сопіги [6] узагальнюються такі фрахові компетентності, які фрормуються під час вивчення дисципліни «Основи проєктування та моделювання», а саме [8, с. 43-47]: графрічна; проєктно-технологічна; інформаційна; художньоконструкторська; автономізаційна (прагнення до саморозвитку, творчості, самовизначення, самоосвіти, конкурентоспроможності); готовність і потреба навчатися протягом усього життя; володіння засобами самопрограмування і технологіями розвитку психологічних здібностей; комунікативна; володіння технологіями усного та писемного спілкування, зокрема через мережу Інтернет різними мовами; вміння брати участь у дискусії, аргументувати свою думку, будувати розповідь; уміння слухати інших і ставити запитання; володіння вербальними та невербальними засобами спілкування.

Науковці О. Марущак, В. Король та Д. Луп'як здійснили аналіз професійних компетентностей майбутнього вчителя технологій, характерних для здійснення навчально-виробничої діяльності, та виділили такі компетентності [5, с. 89-90]: науководослідну, проєктно-конструкторську, виробничотехнологічну, організаційно-управлінську, психолого-педагогічну та інформаційну. На нашу думку, виділеним авторами професійним компетентностям властиве вирішення певного роду професійних завдань і для спеціальності «Професійна освіта» за спеціалізацією «Сорера обслуговування».

Формування фрахових компетентностей майбутніх педагогів професійного навчання і фрахівців сорери обслуговування під час вивчення дисципліни «Основи проєктування та моделювання» має передбачати такі основні принципи організації процесу навчання: науковість, системність, послідовність, гуманізм, активність, зв'язок теорії і практики, індивідуалізація навчання, контекстність навчання, елективність навчання, доступність, рефрлексія власного розвитку [5, с. 90-91].
Окрім того, потрібно врахувати і педагогічні умови, які впливають на фрормування професійної компетентності майбутнього педагога професійного навчання, а саме: зовнішні (сприятливе середовище, науково-методичне забезпечення навчально-виховного процесу), внутрішні (власний потенціал студента, його індивідуальні особливості), матеріальні (комфортні умови навчання через організацію предметного середовища). Формування профресійної компетентності майбутніх педагогів професійного навчання доцільно здійснювати на основі загальних положень системного підходу та використання інших науково обґрунтованих підходів, зокрема міжкультурного, діяльнісного, акмеологічного, розвивального [5, с. 91], особистісно орієнтованого (розвиток і саморозвиток особистості з урахуванням їі здібностей, нахилів, інтересів, ціннісних орієнтацій і суб'єктного досвіду; створення умов для реалізації та самореалізації особистості; можливість обрання студентами змісту, засобів, методів, форм навчання, що забезпечує їхній особистісний розвиток; варіативність) [9].

Сучасна модель освіти має забезпечити інтеграцію різних способів засвоєння навчального матеріалу на основі взаємодії репродуктивних і творчих його елементів, прагнути до культурної наповненості методів навчання, розвитку механізмів передачі засвоєних культурних норм і цінностей. Найважливішими умовами фрормування конкурентоспроможної національної економіки на основі чинників інтелектуально-інноваційного розвитку $€$ створення найсучаснішого освітнього середовища, орієнтованого на гармонізацію національних і міжнародних стандартів вищої освіти; інтеграцію до європейського освітнього простору [10, с. 73]. Потрібно створити таке інтелектуально-інноваційне і художньо-педагогічне освітнє середовище, яке б стало «основою інтелектуального, духовного, фрізичного і культурного розвитку особистості, іï̈ успішної соціалізації, економічного добробуту, запорукою розвитку суспільства, об'єднаного спільними цінностями, культурою і державою» [1].

Інноваційне художньо-педагогічне освітнє середовище характеризується такими ознаками: наявність настанов і позитивної мотивації; здійснення цілеспрямованої, систематичної підготовки студентів до опанування знаннями із психологопедагогічних і професійно орієнтованих дисциплін; формування індивідуально-творчого стилю професійно-педагогічної діяльності; наявність емоційно-сприятливого клімату, взаємостосунків співпраці і співтворчості, діалогового спілкування між викладачами і студентами під час професійної підготовки; створення атмосфери культурно-освітнього середовища, наповненого художньо-мистецьким змістом [11, с. 73]. 
Ураховуючи вимоги стандарту вищої освіти за спеціальністю «015 Професійна освіта (Сорера обслуговування)» для першого (бакалаврського) рівня вищої освіти [12], за яким спеціальність 015 Профресійна освіта передбачає такі цілі навчання, як підготовка фрахівців, здатних здійснювати освітню діяльність із професійної підготовки технічних фрахівців, кваліфікованих робітників і працівників сорери торгівлі і послуг (відповідно до ДК 003:2010) підприємств, установ та організацій сорери обслуговування, можна стверджувати, що вивчення освітнього компонента «Основи проєктування і моделювання» сприятиме розвитку здатностей до перетворювальної діяльності, використанню інфрормаційно-комунікаційних технологій, стимулюванню творчого і науково-дослідного пошуку, фрормуванню відповідальності та самоорганізації у профресійній діяльності, розумінню використання отриманих теоретичних знань і практичних умінь із дисципліни у закладах освіти та в установах сфрери послуг. Тому метою викладання навчальної дисципліни «Основи проєктування і моделювання» є ознайомлення студентів із основними правилами та законами проєктування і моделювання виробів у закладах професійної освіти і у виробничій діяльності сорери послуг; сприяння розвитку пізнавальних інтересів і творчих здібностей, потрібних для майбутньої організації навчання у закладах професійної освіти. Основними завданнями вивчення дисципліни $€$ : навчити здобувачів вищої освіти розробляти навчальні/розвивальні проєкти, враховуючи всі стадії проєктування і розроблення проєктно-конструкторської документації; управляти розробленням проєктів як у закладах професійної освіти, так і в установах сорери послуг.

Ураховуючи мету і завдання вивчення навчальної дисципліни, здобувач вищої освіти повинен знати: основні поняття, стадії, правила проєктування і моделювання у професійній освіті та у виробничій діяльності сорери послуг; вміти: створювати, офрормляти та захищати власні проєкти, використовуючи правила проєктування і моделювання, закони композиції, різноманітні техніки і технології, матеріали; робити рекламу власному виробу, аналізувати рентабельність власної продукції та шукати шляхи її реалізації; навчитися: раціонально розподіляти час на розроблення проєктів, максимально використовуючи інформаційні і комунікаційні технології; працювати у команді та керувати навчальними/розвивальними проєктами як у закладах професійної освіти, так і в установах сорери обслуговування; проєктувати і виготовляти вироби за призначенням, розробляти проєктно-конструкторську документацію і захищати власні проєкти.

Викладання освітнього компонента «Основи проєктування та моделювання» здійснюється на засадах проєктно-технологічного підходу (за О.М. Коберником) із корективами, які стосуються профресійного навчання за спеціалізацією «Сорера обслуговування». Наприклад, завдання для практичних занять можуть бути такого змісту:

1) проєктування і виготовлення об'єктів (виробів) у закладах профрільної середньої, профресійної (профресійно-технічної), позашкільної освіти для установ сорери послуг (мета: навчитися проєктувати вироби, обґрунтовувати вибір і технології для виготовлення комплексного виробу; розробляти рекламні проєкти; здійснювати опис виробу згідно 3 етапами проєктно-технологічної діяльності; робити висновки із технічної пропозиції виробу та обґрунтування його виготовлення):

- виготовлення рекламних листівок для відвідувачів готельно-ресторанного комплексу із відповідною символікою або ж вітальних листівок (наприклад до свята 8 Березня, 3 Днем народження тощо) у різних техніках (скрапбукінг, квіллінг, витинанка, айріс фролдінг, вишивка на папері, орігамі, кардмейкінг тощо) 3 урахуванням освітніх компонент закладів профрільної середньої, професійної (професійно-технічної), позашкільної освіти;

- розроблення рекламного проєкту (вивіска, логотип, буклет, сайт тощо) освітнього закладу чи окремої спеціальності або ж закладу сфери послуг, дотримуючись вимог, які висуваються до створення відповідних рекламних звернень, та спираючись на уже наявні зразки реклами відповідних закладів (представити фрото, рисунки рекламних зразків; провести їхній аналіз, презентувати власну розробку рекламного проєкту);

- проєктування і виготовлення подарункових сувенірів для відвідувачів готельно-ресторанного комплексу із відповідною символікою установи (квіти, статуетки, органайзери, топіарії тощо) або ж комплексного виробу (із оретру, фроамірану, стрічок, дерева, металу тощо з урахуванням різних технік і технологій) для святкового, тематичного чи ділового оздоблення закладів сорери обслуговування (новорічні іграшки, дизайн інтер'єру до 8 Березня, дитячі розвивальні іграшки для зали очікування, дизайн інтер'єру коноеренц-зали тощо); офрормлення проєктно-технологічної документації; представлення, захист та обговорення власного проєкту;

2) моделювання об'ємних композицій у закладах профрільної середньої, профресійної (професійно-технічної), фрахової (передвищої), позашкільної освіти для установ сорери послуг (мета: навчитися використовувати закони композиції під час проєктування і моделювання виробів, предметів інтер'єру для закладів сфрери послуг; робити висновки із технічної пропозиції виробу та обґрунтування його виготовлення):

- створення об'ємної композиції виробу, предметів інтер'єру (з дерева, металу, картону, франери, 
холодного фрарфору, фроамірану, полімерної глини, у техніці декупаж тощо) з урахуванням освітніх компонент закладів профрільної середньої, професійної (профресійно-технічної), фрахової (передвищої), позашкільної освіти або ж для закладів сорери послуг; офрормлення проєктно-технологічної документації; представлення, захист та обговорення проєкту.

Таким чином, під час вивчення дисципліни «Основи проєктування та моделювання» здійснюється фрормування таких спеціальних (фахових) компетентностей [12]: здатність застосовувати освітні теорії і методології у педагогічній діяльності; здатність керувати навчальними/розвивальними проєктами; здатність спрямовувати здобувачів освіти на прогрес і досягнення; здатність використовувати сучасні інорормаційні технології і спеціалізоване програмне забезпечення та інтегрувати їх в освітнє середовище; здатність аналізувати ефективність проєктних рішень, пов'язаних з підбором, експлуатацією, вдосконаленням, модернізацією технологічного обладнання та устаткування сорери обслуговування; здатність використовувати відповідне програмне забезпечення для вирішення професійних завдань у сфері обслуговування; здатність упроваджувати ефективні методи організації праці відповідно до вимог екологічної безпеки, безпеки життєдіяльності та охорони і гігієни праці; здатність використовувати у професійній діяльності основні положення, методи, принципи фрундаментальних і прикладних наук; здатність виконувати розрахунки технологічних процесів у галузі; здатність управляти комплексними діями/проєктами, відповідати за прийняття рішень у непередбачуваних умовах, за професійний розвиток здобувачів освіти і підлеглих; здатність збирати, аналізувати та інтерпретувати інсрормацію (дані) відповідно до спеціалізації сорери обслуговування.

Висновки з даного дослідження та подальші перспективи розвідок у даному напрямку. Дослідження питання про формування профресійної компетентності майбутніх педагогів профресійного навчання за спеціалізацією «Сорера обслуговування» під час вивчення освітнього компонента «Основи проєктування та моделювання», дозволяє стверджувати, що зазначене поняття є ціллю фахової професійно-педагогічної підготовки фрахівців, адже містить вимоги до знань, умінь, навичок, норм і цінностей. Під час вивчення основ проєктування і моделювання формуються такі фрахові компетентності: графічна, проєктно-технологічна, інфрормаційна, художньо-конструкторська, автономії, комунікативна; науково-дослідна, проєктноконструкторська, виробничо-технологічна, організаційно-управлінська, психолого-педагогічна та інфрормаційна.

Формування профресійної компетентності майбутніх педагогів професійного навчання і фрахівців сорери обслуговування під час вивчення дисципліни «Основи проєктування та моделювання» має передбачати основні принципи організації процесу навчання (принципи науковості, системності, послідовності, гуманізму, активності, зв'язку теорії із практикою, індивідуалізації навчання, контекстності, елективності, доступності, рефлексії власного розвитку) і науково обгрунтовані підходи (системний, діяльнісний, індивідуальний, акмеологічний, особистісно орієнтований), а також відбуватись із застосуванням сучасних технологій навчання (інформаційно-комунікаційних, інтерактивних, проєктних, програмного забезпечення тощо). Отже, врахування вищезазначених аспектів дозволить досягти ефективних результатів у фрормуванні профресійної компетентності майбутніх педагогів професійного навчання і фрахівців сорери обслуговування зокрема та їхньої педагогічної майстерності загалом, а також сприятиме розвитку внутрішнього духовно-морального життя людської особистості, культури і толерантності, творчості і креативності, саморозвитку та самоствердження особистості з урахуванням здібностей, нахилів, інтересів, ціннісних орієнтацій і суб'єктного досвіду. Подальші дослідження ми пов'язуємо з виробленням методичних рекомендацій щодо викладання цієї дисципліни та самостійної роботи здобувачів вищої освіти в умовах змішаного (очного, дистанційного) навчання.

\section{БІБЛІОГРАФІЧНИЙ СПИСОК:}

1. Закон України про освіту / ВВР. 2017. № 38-39. Ст. 380

2. Ганжа М.В. Потенціал мистецтва дизайну у формуванні художнього досвіду студентів. Інноваційна педагогіка. 2020. Вип. 21, т. 1. С. 174-177.

3. Фурса О. О. Тенденції розвитку дизайн-освіти в Україні (друга половина XX - початок XXI століття) : автореф. дис... доктора пед. наук: 13.00.01. Житомир. держ. ун-т ім. Івана Франка. Житомир, 2014. $40 \mathrm{C}$.

4. Вдовиченко Р.П. Між професійною підготовкою та компетентністю. Управління освітою (Шкільний cвim). 2003. № 15-16. С. 2-3.

5. Марущак О., Король В., Луп'як Д. Формування профресійної компетентності майбутнього вчителя технологій. Наукові записки. Серія: Проблеми методики фрізико-математичної і технологічної освіти. 2015. Вип. 7(I). С. 88-91.

6. Сорока Т.П., Сопіга В.Б. Формування професійних компетентностей майбутніх фрахівців сорери обслуговування в процесі вивчення дисципліни «Основи проєктування та моделювання». Вісник Черкаського університету. Серія «педагогічні науки». 2019. Вип. 2. С. 133-137.

7. Захарченко В.М. та ін. Національний освітній глосарій : вища освіта. 2-е вид., перероб. і доп.; за ред. В.Г. Кременя. Київ, 2014. 100 с.

8. Гедзик А.М., Коберник О.М., Ткачук C.I., Ящук С.М. та ін. Компетентнісний підхід у профресійній підготовці майбутніх вчителів технологій: колек- 
тивна монографрія. Умань: Сочінський М.М., 2017. $280 \mathrm{c}$.

9. Мироненко Н. Особистісно орієнтоване навчання у процесі викладання дисципліни "Основи проектування та моделювання". Наукові записки Кіровоградського державного педагогічного універcumemу імені Володимира Винниченка. Серія : Проблеми методики фрізико-математичної і технологічної освіти. 2016. Вип. 12(1). С. 127-131.

10. Богатирьова Г.А. Культурологічний складник підготовки фрахівців сорери туризму та гостинності в умовах полікультурності. Інноваційна педагогіка. 2021. Вип. 35. С. 69-73.

11. Горянський В.В. Концептуальні підходи до формування фрахової компетентності в умовах вищої мистецької освіти, зокрема у процесі професійної підготовки майбутніх бакалаврів дизайну. Інноваційна педагогіка. 2021. Вип. 31, т. 1. С. 71-74.

12. Стандарт вищої освіти за спеціальністю «015 Профресійна освіта (Сорера обслуговування)» для першого (бакалаврського) рівня вищої освіти (Наказ МОНУ № 1460 від 21.11.2019 р.). 